\title{
THE PREVALENCE OF ALCOHOL CONSUMPTION BY ADOLESCENTS IN SERBIA AND ITS CORRELATION WITH SOCIODEMOGRAPHIC FACTORS - A NATIONAL SURVEY
}

Snezana Radovanovic ${ }^{1}$, Dragan Vasiljevic ${ }^{2}$, Sanja Kocic ${ }^{1}$, Svetlana Radevic ${ }^{3}$, Mirjana Milosavljević ${ }^{4}$ and Nataša Mihailovic ${ }^{4}$ ${ }^{1}$ Department of Social Medicine, Faculty of Medical Sciences, University of Kragujevac and Institute of Public Health, Kragujevac, Serbia ${ }^{2}$ Department of Hygiene, Faculty of Medical Sciences, University of Kragujevac, Serbia and Institute of Public Health, Kragujevac, Serbia ${ }^{3}$ Department of Social Medicine, Faculty of Medical Sciences, University of Kragujevac, Serbia ${ }^{4}$ Institute of Public Health, Kragujevac, Serbia

\author{
RASPROSTRANJENOST KONZUMIRANJA ALIOHOLA \\ KOD ADOLESCENATA U SRBIJI I POVEZANOST SA \\ SOCIODEMOGRAFSKIM FAKTORIMA- NACIONALNO ISTRAŽIVANJE \\ Snežana Radovanović ${ }^{\text {, Dragan Vasiljević }}{ }^{2}$, Sanja Kocić ${ }^{1}$, Svetlana Radevićs, Mirjana Milosavljević ${ }^{4}$ i Nataša Mihailović $^{4}$ \\ ${ }^{1}$ Katedra za socijalnu medicine, Fakultet medicinskih nauka, Univerzitet u Kragujevcu i Institut za javno zdravlje, Kragujevac, Srbija \\ ${ }^{2}$ Katedra za higijenu, Fakultet medicinskih nauka, Univerzitet u Kragujevcu i Institut za javno zdravlje, Kragujevac, Srbija \\ ${ }^{3}$ Fakultet medicinskih nauka, Univerzitet u Kragujevcu, Srbija \\ ${ }^{4}$ Institut za javno zdravlje, Kragujevac, Srbija
}

Received / Primljen: 04. 03. 2016.

Accepted / Prihvaćen: 17. 03. 2016.

\begin{abstract}
The aim of this study was to determine the prevalence of alcohol consumption among adolescents in Serbia and its association with sociodemographic characteristics. This paper is based on data from a national health survey of the population of Serbia in 2013 (no data for Kosovo and Metohija), conducted by the Ministry of Health of the Republic of Serbia. For the purposes of this study, data on households and individuals over 15 years of age were used; thus, the final sample for analysis included 858 patients (aged 15 to 19 years). Researchers used demographic characteristics (age, gender, type of home, region) and socioeconomic characteristics (income per household member, the index of well-being, self-assessment of health, cigarette smoking, tendency towards psychological and physical violence) as the independent variables. A $\chi 2$ test was applied to test the differences in the frequencies of categorical variables. The correlations between alcohol consumption, as the dependent variable, and the independent variables (mentioned above) were tested by logistic regression. All results less than or equal to $5 \%$ probability ( $p$ $\leq 0.05)$ were considered statistically significant. The prevalence of alcohol consumption among adolescents in Serbia is 51.6\%. Alcohol consumption is significantly associated with sex, type of home and the index of well-being $(p<0.05)$. The prevalence of alcohol consumption is higher in males (57.1\%), in adolescents who come from urban areas (59.3\%) and in adolescents who, according to the index of well-being, belong to the wealthiest financial category (23.9\%).
\end{abstract}

Keywords: alcohol, prevalence, adolescents, Serbia

\section{SAŽETAK}

Cilj rada je utvrdivanje prevalence konzumiranja alkohola kod adolescenata u Srbiji i povezanost sa sociodemografskim karakteristikama. Rad je zasnovan na podacima nacionalnog istraživanja zdravlja stanovništva Srbije u 2013. godini (bez podataka za Kosovo i Metohiju), koje je sprovelo Ministarstvo zdravlja Republike Srbije. Za potrebe ovog rada korišćeni su podaci o domaćinstvima $i$ stanovništvu starosti 15 i više godina, tako da je u konačni uzorak za analizu ušlo 858 ispitanika (starosti 15 do 19 godina). Od nezavisnih varijabli u istraživanju su korišćena demografska obeležja (starost, pol, tip naselja, region) $i$ socijalno-ekonomske odlike (prihodi po članu domaćinstva, indeks blagostanja, samoprocena zdravlja, konzumiranje cigareta, sklonost ka psihičkom i fizičkom nasilju). Za ispitivanje razlika u učestalosti kategorijskih varijabli primenjen je X2 test. Povezanost konzumiranja alkohola, kao zavisne varijable, $i$ nezavisnih varijabli (gore pomenutih) ispitivana je logističkom regresijom. Statistički značajnim smatrali su se svi rezultati gde je verovatnoća jednaka ili manja od 5\% (p $\leq$ 0.05). Prevalenca konzumiranja alkohola medu adolescentima u Srbiji iznosi 51,6\%. Konzumiranje alkohola značajno je povezano sa polom, tipom naselja i indeksom blagostanja (p<0.05). Prevalenca konzumiranja alkohola veća je kod muškaraca (57,1\%), kod adolescenata koji potiču iz gradske sredine (59,3\%) i kod adolescenata koji prema indeksu blagostanja pripadaju kategoriji najbogatijih (23,9\%).

Ključne reči: alkohol, prevalenca, adolescenti, Srbija 


\section{INTRODUCTION}

Adolescence is defined as a period of transition from childhood to adulthood that is characterized by efforts to meet the expectations of one's culture, as well as the requirements of physical, mental, emotional and social development. This is a period of development that has its own characteristics in biological, psychological and social terms (1).

Insecurity, instability of mood, lack of spontaneity, egocentricity, rebelliousness, conflicts with authority, fear of failure, and a desire to be successful are features that characterize the personalities and behaviours of adolescents (2).

The period of adolescence is described as a time of experimentation with risky behaviours, which has an adaptive purpose as young people gain experience and skills (3). However, adolescents are immature and unprepared and are thus prone to engaging with all that their environments provide and more frequently resorting to various problematic behaviours, of which some do not always have positive and adaptive functions (4).

There are common initial motives for consuming alcohol in adolescent populations: the desire to satisfy curiosity; the need to belong to a group; and the desire to have new experiences, avoid boredom, escape from problems, and reduce social fears and uncertainty (5).

\section{THE AIM OF THE WORK}

The aim of this work was to determine the prevalence of alcohol consumption among adolescents in Serbia and its association with sociodemographic characteristics.

\section{METHODS}

\section{Data source and type of study}

This paper is based on data from a national health survey of the population of Serbia in 2013 (no data for Kosovo and Metohija). This is the third national survey of health of the population, conducted by the Ministry of Health of the Republic of Serbia. The first such survey was conducted in 2000 , and the second was conducted in 2006. The survey was conducted in accordance with the methodology and instruments of the European Health Survey - Second Wave (EHIS-wave 2). The health survey of the Serbian population was carried out through interviews, anthropometric measurements and blood pressure measurements. We used a nationally representative random sample: a stratified two-stage sample with a known probability of selection of sample units at every stage of sampling. The sample was selected to provide a statistically reliable estimate of the large number of indicators of the health of the population at the national level.

The mechanisms used to obtain a random sample of households and respondents represent a combination of two sampling techniques: stratification and multi-stage sampling. For the purposes of this study, data on households and individuals over 15 years of age were used; thus, the final sample for analysis included 858 patients (aged 15 to 19 years).

\section{Variables}

Researchers used demographic characteristics (age, gender, type of home, region) and socio-economic characteristics (income per household member, the index of well-being, self-assessment of health, cigarette smoking, tendency towards psychological and physical violence) as the independent variables.

\section{Statistical data analysis}

All data of interest were analysed by adequate mathematical-statistical methods appropriate for the data type. A $\mathrm{x} 2$ test was applied to test the differences in the frequencies of categorical variables. The correlations between alcohol consumption, as the dependent variable, and the independent variables (mentioned above) were tested by logistic regression.

All results less than or equal to $5 \%$ probability $(\mathrm{p} \leq 0.05)$ were considered statistically significant. Statistical analysis was performed using a commercial, standard software package SPSS, version 19.0 (The Statistical Package for Social Sciences software; SPSS Inc., version 19.0, Chicago, IL).

\section{RESULTS}

The prevalence of alcohol consumption among adolescents in Serbia is $51.6 \%$. One in ten adolescents (10.1\%) claimed to consume alcoholic drinks once or twice a week, while $24 \%$ of adolescents said that they drink one to three times a month. When asked how many days they drink from Monday to Thursday, the highest percentage of adolescents claimed to drink alcohol one day out of four (16.9\%), while one in three adolescents in our study (35.1\%) claimed to drink one day from Friday to Sunday. The largest percentage of adolescents (14.6\%) drinks six or more alcoholic drinks on one occasion once a month (e.g., at parties, with food, during evenings spent with friends, alone at home). In terms of the type of alcoholic beverage, commonly consumed beverages include liquor, beer and wine. Analysis of the influence of sociodemographic factors on the prevalence of alcohol consumption among adolescents in Serbia (shown in Table 1) showed that alcohol consumption is significantly associated with sex, type of home and the index of well-being ( $\mathrm{p}$ $<0.05$ ). The prevalence of alcohol consumption was higher in males (57.1\%), in adolescents who come from urban areas (59.3\%) and in adolescents who, according to the index of well-being, belong to the wealthiest financial category (23.9\%). It was also observed that adolescents who smoke cigarettes more often drink alcohol (75.1\%) and that ado- 
Table 1. The prevalence of alcohol consumption among adolescents in Serbia in relation to sociodemographic characteristics

\begin{tabular}{|c|c|c|c|c|}
\hline \multicolumn{2}{|c|}{ Variables } & $\begin{array}{l}\text { Alcohol consumption } \\
\mathrm{n}(\%)\end{array}$ & $\begin{array}{c}\text { Not alcohol consumtion } \\
\mathrm{n}(\%)\end{array}$ & $\mathrm{p}^{*}$ \\
\hline \multirow{2}{*}{ Gender } & Male & $233(57.1)$ & $169(44.2)$ & \multirow{2}{*}{$\mathrm{p}<0.001$} \\
\hline & Female & 175 (42.9) & $213(55.8)$ & \\
\hline \multirow{2}{*}{ Type of settlement } & Urban & $242(59.3)$ & $185(48.4)$ & \multirow{2}{*}{$\mathrm{p}<0.001$} \\
\hline & Rural & $166(40.7)$ & $197(51.6)$ & \\
\hline \multirow{4}{*}{ Region } & Belgrade & $84(20.6)$ & $69(18.1)$ & \multirow{4}{*}{$\mathrm{p}>0.05$} \\
\hline & Vojvodina & $114(27.9)$ & $88(23.0)$ & \\
\hline & Šumadija and Western Serbia & $109(26.7)$ & $116(30.4)$ & \\
\hline & South-East Serbia & $101(24.8)$ & $109(28.5)$ & \\
\hline \multirow{6}{*}{ Income per household } & Do 9.000 & $110(27.0)$ & $136(35.6)$ & \multirow{6}{*}{$\mathrm{p}>0.05$} \\
\hline & $9.001-14.000$ & $95(23.3)$ & $78(20.4)$ & \\
\hline & $14.001-20.000$ & $70(17.2)$ & $59(15.4)$ & \\
\hline & $20.001-29.000$ & $36(8.8)$ & $21(5.5)$ & \\
\hline & Preko 29.000 & $15(3.7)$ & $13(3.4)$ & \\
\hline & refuses to answer & $82(20.1)$ & $75(19.6)$ & \\
\hline \multirow{5}{*}{ Well-being index } & Poorest & $60(14.7)$ & $80(20.9)$ & \multirow{5}{*}{$\mathrm{p}<0.05$} \\
\hline & Poorer & $73(17.9)$ & $81(21.2)$ & \\
\hline & Middle & $81(19,9)$ & $82(21.5)$ & \\
\hline & Richer & $97(23.7)$ & $78(20.4)$ & \\
\hline & Richest & $98(23.9)$ & $61(16.0)$ & \\
\hline \multirow{5}{*}{ Self-assessed health } & Very good & $274(67.2)$ & $257(67.3)$ & \multirow{5}{*}{$\mathrm{p}>0.05$} \\
\hline & Good & $121(29.7)$ & $112(29.3)$ & \\
\hline & Fair & $11(2.7)$ & $10(2.6)$ & \\
\hline & Bad & $1(0.2)$ & $3(0.8)$ & \\
\hline & Very bad & $1(0.2)$ & 0 & \\
\hline \multicolumn{2}{|c|}{ The tendency to psychological violence } & $50(76.9)$ & $15(23.1)$ & $\mathrm{p}<0.001$ \\
\hline \multicolumn{2}{|c|}{ The tendency to physical violence } & $46(50.7)$ & $11(19.3)$ & $\mathrm{p}<0.001$ \\
\hline \multicolumn{2}{|c|}{ The consumption of cigarettes } & $145(75.1)$ & $48(24.9)$ & $\mathrm{p}<0.001$ \\
\hline
\end{tabular}

${ }^{*}{ }^{2}$ (chi-squared)

lescents who consume alcohol are more likely to have experienced psychological (76.9\%) and physical abuse (50.7\%). These results are statistically significant $(\mathrm{p}<0.05)$.

To examine the impact of certain predictors on alcohol consumption, binary logistic regression was applied. A significant contribution to the model was made by three independent variables: gender, financial status and tobacco consumption. The strongest predictor was tobacco smoking, with a probability coefficient of 3.99. In fact, individuals who smoke were almost 4 times more likely to consume alcohol than non-smokers. Males were 1.74 times more likely to consume alcohol than females. Respondents who belong to the wealthiest financial category more often consume alcohol $(\mathrm{OR}=1.18)($ Table 2$)$.

\section{DISCUSSION}

Alcohol is a psychoactive substance that is commonly used and abused by adolescents worldwide (6). During adolescence, alcohol consumption is of great importance be- cause of the frequency and extent of its use and its impact on the health of adolescents (7). Studies of alcohol consumption among European adolescents (ESPAD) indicate that the use of alcohol among young people in almost all European countries is on the rise (8), despite the fact that much research shows that high school students are well informed about the health risks arising from the consumption of alcohol (9). Our results show a lower incidence of alcohol consumption among adolescents in Serbia (51.6\%) than among adolescents in many other European countries, such as Romania and Sweden (71-74\%); Montenegro, Norway, Albania and Iceland (65-43\%) (10); Italy (63.3\%) (11); Germany (52.3\%) (12); and the US (71\%) (13). However, our results are higher than those recorded in the 2006 study of the health of the Serbian population (48.7\%) (14). Alcohol consumption by young people is a national problem in many countries, primarily due to the harmful effects of alcohol consumption on the social, physical and neurological development of adolescents. Nearly two-thirds of Australian adolescents consume alcohol (15), as well as $50 \%$ of adolescents in Brazil 
Table 2. Logistic regression analyses

\begin{tabular}{|c|c|c|c|c|c|}
\hline \multirow{2}{*}{ Variables } & \multirow{2}{*}{$\mathrm{B}$} & \multirow{2}{*}{$\operatorname{Exp}(B)$} & \multicolumn{2}{|c|}{ 95\% C.I.for $\mathrm{EXP}(\mathrm{B})$} & \multirow{2}{*}{$\mathrm{p}$} \\
\hline & & & Lower & Upper & \\
\hline $\operatorname{Sex}(1)$ & 0.55 & 1.730 & 1.278 & 2.341 & 0.000 \\
\hline Region & -0.07 & .933 & .809 & 1.076 & 0.339 \\
\hline settlement type & -0.11 & .898 & .614 & 1.313 & 0.578 \\
\hline financial situation & 0,17 & 1,181 & 1.028 & 1.356 & 0.019 \\
\hline income & 0,00 & 1.000 & 1,000 & 1,000 & 0.648 \\
\hline self-assessment of health & -0.03 & ,972 & .746 & 1.267 & 0.836 \\
\hline Smoking & 1.38 & 3.992 & 2.736 & 5.825 & 0.000 \\
\hline psychological abuse & 0.00 & 1.000 & 1.000 & 1.000 & 0.669 \\
\hline physical abuse & 0.00 & 1.000 & 1.000 & 1.000 & 0.797 \\
\hline
\end{tabular}

(16). Alcohol consumption among young people is a major public health problem in the U.S. More than $27 \%$ of 12 to 20 year-olds drink alcohol throughout the year, averaging almost 5 drinks per session. Excess alcohol consumption increases the risk of acute and chronic alcohol-related problems, including risky sexual behaviour, injury and driving while intoxicated. Those who begin drinking alcohol as juveniles are more likely to develop symptoms of alcohol abuse and dependence as an adult than their peers who abstain from alcohol use (17). In our study, alcohol consumption in adolescents was significantly associated with sex, type of home and the well-being index, which corresponds to the results recorded in most other countries. It has been noted that young men consume alcohol more than women in Canada (18), Croatia (19), Italy (11), Iceland, Latvia and Sweden (10), and Germany (12), which corresponds to our results, while research in the United States (13) shows that women are more likely consume alcohol than men. Additionally, it was found that adolescents of higher socio-economic status (11) frequently consume alcoholic beverages, which is confirmed by our national survey. Other studies (Great Britain) have shown that the use of alcohol among adolescents is more frequent in households with higher incomes (20). There are predisposing factors to alcohol consumption in Spanish adolescents: frequently going out for fun in the evenings, high proportions of friends who drink or get drunk, early onset of alcohol use, low perceived risk of drinking, truancy, illegal drug use, and the amount of money spent on personal needs (21). Higher household income was associated with a greater risk of alcohol use (22). In our study, adolescents in urban areas more frequently consume alcohol; however, other studies have shown that young people from rural areas frequently consume alcohol. Apparently, in this case, adolescents with rural residences have fewer alternatives for inclusion in interesting leisure activities than adolescents who live in cities. This may be one reason for the more problematic patterns of consumption in this environment (23).

Adolescents who consume alcohol are more prone to other health risk behaviours, such as riding with a driver who has been drinking, engaging in risky sexual activity, cigarette smoking, and using illicit drugs, and are more likely to become the victims of violence or suicide, which has been shown in the results of many studies $(24,11,25)$. Our research also supports previous facts as we observed that adolescents who consume alcohol are more often smokers and are more susceptible to mental (psychological harassment, insults) and physical violence (fights). Even a single episode of heavy drinking in adolescence significantly increases the risk of morbidity and mortality caused by negligent driving, various incidents, accidents and risky sexual activity (26). The results of certain studies show that alcohol is a leading cause of murder, suicide and accidents resulting in death in adolescence; more adolescents lose their lives due to the consequences of alcohol than due to the use of all other psychoactive substances combined (27). A large number of adolescents (70\% of boys and $53 \%$ of girls) who have used alcohol more than five times in their lives state that they have experienced at least one problem associated with the use of alcohol (e.g., problems with the law, health problems, absence from school or going to school under the influence of alcohol, etc.) (28).

Primary socialization and education occurs in families and is the most important influence on adolescent health behaviour; parents model social and health behaviour patterns. The attitudes of parents, who can directly approve or indirectly support the abuse of alcohol, have a direct relevance for the formation of attitudes of adolescents, especially if there is a case of alcoholism in the family (29). It is therefore necessary to focus prevention programs on creating a harmonious relationship in the family and on preventing marital conflicts and child abuse and neglect.

\section{CONCLUSION}

The results of this research indicate that there is an increased prevalence of alcohol consumption among adolescents in Serbia. It is therefore very important to carry out preventive measures to prevent and control the risks of alcohol abuse by young people. These measures should include individuals, as well as families, schools, health institutions and society as a whole. Preventive activities should be conducted in an organized way, beginning in early childhood, at all levels of society. 


\section{REFERENCES}

1. Vukomanović S. I. Procena mentalnog zdravlja i prevencija mentalnih poremećaja studentske populacije. Doktorska disertacija, Fakultet medicinskih nauka Univerziteta u Kragujevcu, Kragujevac, 2015.

2. Mitrović D, Smederevac S, Grujičić S, Čolović P. Tipološki pristup rizičnom ponašanju adolescenata. Zbornik Instituta za pedagoška istraživanja 2006;(1): 264-78.

3. Petrović J, Mihić I, Zotović M. Forme i učestalost rizičnih ponašanja kod studentkinja novosadskog univerziteta. Pedagoška stvarnost 2007; (9-10): 875-91.

4. Marić M. Problematično ponašanje dece i adolescenata - pojam, učestalost, poreklo i prevencija. Norma 2011; 16(2): 175-83.

5. Dragišić-Labaš S, Milić M. Bolesti zavisnosti kao bolesti društva, porodice i pojedinca. Sociologija 2007; 49(1): 31-43.

6. Melotti R, Lewis G, Hickman M, Heron J, Araya R and Macleod J. Early life socio-economic position and later alcohol use: birth cohort study. Addiction 2013; 108(3): 516-525.

7. Rakić D, B. Rakić B, Milošević Z, Nedeljković I. The prevalence of substance use among adolescents and its correlation with social and demographic factors. Vojnosanitetski pregled 2014; 71(5):467-473.

8. Republika Srbija Ministarstvo zdravlja. Evropsko istraživanje o upotrebi alkohola i drugih droga među mladima u Srbiji. Beograd: Ministarstvo zdravlja; 2008.

9. Nieradko B, Swies Z, Milczanowska K, Sieklucka-Dziuba $M$. Frequency analysis of the use of addictive substances by adolescents attending secondary schools in Sanok. Wiad Lek 2002; 55(1): 818-24.

10. Hibell B, Guttormsson U, Ahlström S, Balakireva O, Bjarnason T, Kokkevi A, et al. The 2011 ESPAD Report - Substance Use Among Students in 36 European Countries. Stockholm, Sweden: The Swedish Council for Information on Alcohol and Other Drugs (CAN); 2012.

11. Flotta D, Micò R, Nobile CG, Pileggi C, Bianco A, Pavia $M$. Consumption of energy drinks, alcohol, and alcohol-mixed energy drinks among Italian adolescents. Alcohol Clin Exp Res. 2014; 38(6):1654-61.

12. Donath C, Gräßel E, Baier D, Pfeiffer C, Bleich S, and Hillemacher T. Predictors of binge drinking in adolescents: ultimate and distal factors - a representative study. BMC Public Health. 2012; 12: 263.

13. Eaton DK, Kann L, Kinchen S, Shanklin S, Flint KH, Hawkins J, et al. Youth risk behavior surveillance United States, 2011. MMWR Surveill Summ 2012; 61(4): 1-162.

14. Radovanović S. Faktori rizika za zloupotrebu psihoaktivnih supstanci kod mladih u Srbiji. Doktorska disertacija, Fakultet medicinskih nauka, Kragujevac, 2013.

15. Sharrad S, De Crespigny C, Aylward P, Wiechula R. An exploration of adolescents' decisions to abstain or refrain from alcohol consumption in Australian social settings: a qualitative systematic review. BI Database System Rev Implement Rep. 2015;13(10):156-179.

16. Malta DC, Machado IE, Porto DL, da Silva MM, de Freitas PC, da Costa AW, Oliveira-Campos M. Alcohol consumption among Brazilian Adolescents according to the National Adolescent School-based Health Survey (PeNSE 2012). Rev Bras Epidemiol. 2014;17(1):203-14.

17. Wechsler H, Lee JE, Nelson TF, Kuo M. Underage college students' drinking behavior, access to alcohol, and the influence of deterrence policies. Findings from the Harvard School of Public Health College Alcohol Study. J Am Coll Health. 2002; 50(5):223-36.

18. National Population Health Survey of Canada: The NTW Health Status Report-1999. Available from: http //www.hc-sc.gc.ca.

19. Hrvatski zavod za javno zdravstvo. Ponašanje u vezi sa zdravljem u djece školske dobi 2001/2002. Zagreb: Hrvatski zavod za javno zdravstvo; 2004.

20. Melotti R, Heron J, Hickman M, Macleod J, Araya R, Lewis G. Adolescent alcohol and tobacco use and early socioeconomic position: the ALSPAC Birth Cohort. Pediatrics. 2011;127(4):948-955

21. Llorens N, Barrio G, Sánchez A, Suelves J, Group EW. Effects of socialization and family factors on adolescent excessive drinking in Spain. Prev Sci. 2011;12(2):150161.

22. Melotti R, Lewis G, Hickman M, Heron J, Araya R, Macleod J. Early life socio-economic position and later alcohol use: birth cohort study. Addiction 2013; 108(3):516-25.

23. Donath C, Grässel E, Baier D, Pfeiffer C, Karagülle D, Bleich S, Hillemacher T. Alcohol consumption and binge drinking in adolescents: comparison of different migration backgrounds and rural vs. urban residence-a representative study. BMC Public Health. 2011; $7(11): 84$.

24. Miller JW, Naimi TS, Brewer RD, Jones SE. Binge drinking and associated health risk behaviors among high school students. Pediatrics 2007; 119(1): 76-85.

25. Scholz M, Kaltenbach M. Cigarette, alcohol and drug use in 12 to 13-year-old adolescents--an anonymous survey of 2,979 students. Gesundheitswesen 1995; 57(6): 339-44.

26. Republika Srbija Ministarstvo zdravlja. Evropsko istraživanje o upotrebi alkohola i drugih droga među mladima u Srbiji. Beograd: Ministarstvo zdravlja; 2008.

27. Chassin L, Hussong A, Barrera M, Molina BG, Trim R, Ritter J. Adolescent substance use. In: Lerner RM, Steinberg L, editors. Handbook of adolescent American Psychiatric Association. Diagnostic and statistical manual of mental disorders. Washington: DC Author; 2004.

28. Marić M. Činioci upotrebe psihoaktivnih supstanci u adolescenciji. Doktorska disertacija, Filozofski fakultet Univerziteta u Novom Sadu, Novi Sad, 2011.

29. Lauvie M, Bates ME, Pandina RJ. Age of first use its reliabity and preventive alcohol by adolescents. J Int Press 2007; 98(9): 57-4. 


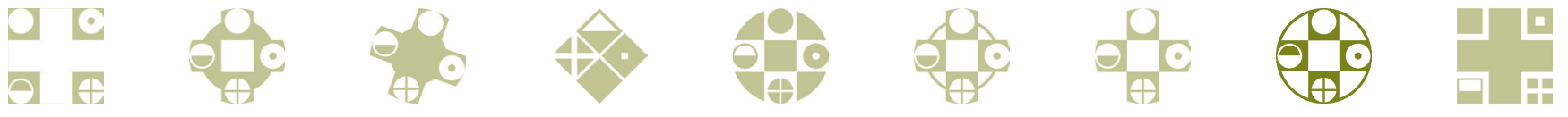

